\title{
ESP Needs Analysis: A Case Study of PEH Students, University of Khartoum
}

\author{
Abuelgasim Sabah Elsaid Mohammed Ibrahim \\ University of Khartoum, Sudan
}

\begin{abstract}
Needs analysis is considered a necessary first step in designing ESP courses. This study, therefore, aims at analysing students at the Faculty of Public and Environmental Health (PEH) at the University of Khartoum (U of K), Sudan, needs for English language. The study adopted the needs analysis framework suggested by Dudley-Evans and St John (1998) focusing on target needs analysis, present situation analysis, and learning means needs analysis. The study used a questionnaire, a proficiency test, and an interview to collect data. The participants were 490 students at PEH (390 participated in the questionnaire and 100 in the proficiency test) and two professors at the Faculty. The study found that PEH students need English language for academic study. The students rated their proficiency as good, but the test revealed that they were of weak proficiency. All the four skills in addition to vocabulary, grammar, and pronunciation are regarded as important to the students. Similarly, almost all the sub-skills are found to be important. The students have a variety of learning needs such as learning in pairs, groups, and through ICT. The study recommends that PEH students' proficiency should be raised and a course that meets the students' needs is needed.
\end{abstract}

Keywords: English for Specific Purposes, needs analysis, present situation, target situation

\section{Introduction}

After the end of the Second World War, tremendous development happened in science, technology, and economics. This development was international, and consequently an international language was required. Due to the economic position of the United States, English language became that language (Hutchinson \& Waters, 1987). Accordingly, learning English has become purposeful, not only for pleasure, but because it is the language of technology and commerce (ibid.). Learners of English have become more aware of the reason for which they were learning English language.

These learners can be classified into two groups. The first are those who study English for their jobs such as doctors or businessmen. The second are students at tertiary level who need to read the literature in their specialization, the majority of which is found in English language (Hutchinson \& Waters, 1987; Lynch \& Hudson, 1991).

As a result, learning English is needed to fulfill two types of needs: immediate and future needs. The former, is the needs of students who require English to succeed in their academic study. The latter, is the needs related to job requirements, environment, or workplace such as an engineer who needs to consult manuals in English, and a practicing doctor who needs to cope with the latest developments in his field (Hutchinson \& Waters, 1987).

Abuelgasim Sabah Elsaid Mohammed Ibrahim, assistant professor, Ph.D., English Language Institute, University of Khartoum. 
In Sudan, Arabic was adopted as the language of instruction in universities in 1989 (Nur \& Mohammed, 2012). Consequently, English language became a subject taught as a university requirement to undergraduates. In University of Khartoum ( $\mathrm{U}$ of $\mathrm{K}$ ), English was taught over two academic years under the supervision of the English Department, the Administration for University Requirements (AUR). Students study 90 hours divided into the first two academic years. In the first year (45 hours), they study General English (GE), and in the other 45 hours, they study English for Specific Purposes (ESP) (Ibrahim, 2010; Nur \& Mohammed, 2012). The ESP courses taught by the Department of English, AUR, are not based on any kind of needs analysis. The material is selected by the instructors based on their perception. This case applies to the ESP course taught at the Faculty of Public and Environmental Health (PEH), U of K.

There are four departments at the Faculty of PEH: Environmental Health and Environmental Studies, Food Hygiene, Epidemiology, and Health Education. In addition, the Faculty provides a Master in Public Health (MPH) Programme. The MPH teaching is through English language.

Despite the importance of NA in ESP course design or material selection, the ESP courses taught at U of $\mathrm{K}$ were not preceded by any type of needs analysis. It seems that teaching ESP at U of K lacks solid base to provide effective courses. It is, therefore, the purpose of this study to analyze PEH students' needs for English language. Thus, the study attempts to answer the following questions:

(1) What are the purposes for which PEH students need English language?

(2) What is PEH students' present situation in English language?

(3) What are the most important English language skills for PEH students?

(4) What are PEH students' learning needs for learning ESP?

\section{Literature Review}

Scholars such as Hutchinson and Waters (1987), Nunan (1988), Brindley (1989), Robinson (1991), Brown (1995) and (2009), Seedhouse (1995), West (1997), Dudley-Evans and St. Johns (1998), Graves (2000), Richards (2001), Long (2005), and Brown (2009) agree that needs analysis (NA) plays an important role in ESP or GE course design, and it must be the first step in the design process. To identify students' need, a number of approaches are identified. The first is target situation analysis (TSA) which refers to what students need to do in the target situation. It includes necessities, lacks, and wants (Hutchinson \& Waters, 1987). According to Hutchinson and Waters (1987), necessities mean what the students must know to perform well in the target situation. Lacks are used to refer to the gap between the students' present proficiency and the target situation (what students do not know). Wants represent what students feel they want to study which may conflict with necessities and lacks (Hutchinson \& Waters, 1987).

The second approach to needs is present situation analysis (PSA). This approach seeks to identify students' present proficiency in English and their level in the language at the beginning of the course (Dudley-Evans \& St Johns, 1998; Robinson, 1991). The third approach is learning needs analysis (LNA) which is used to refer to, "What the learner needs to do in order to learn" (Hutchinson \& Waters, 1987, p. 54). For them, it is not acceptable to base an ESP course on objectives resulted from the TSA. To conduct an effective NA, the potential constraints of the route (the learning situation) must be accounted for (Hutchinson \& Waters, 1987). LNA caters for the skills students need, the learning process, students' motivation, and learners' individual differences (Dudley-Evans \& St John, 1998). The fourth approach to NA is means analysis. According to Dudley-Evans and St John (1998) means analysis offers data about the surroundings in which the ESP course 
will be taught. It focuses on the classroom and the administration infrastructure, and culture.

There is a common agreement on the variety of the methods used to collect data in NA. For example, Basturkmen (2010), Brown (1995, 2009), Long (2005), Hyland (2006), Richards (2001), Graves (2000), Dudley-Evans and St John (1998), and West (1997) agree that NA can be conducted using questionnaires, observations, interviews, tests, and analysis of authentic spoken and written texts.

Questionnaires are one of the instruments used to collect NA data. They are used to gather information on a larger scale (Brown, 1995; Dudley-Evans \& St John, 1998; Graves, 2000). They can cover questions, which interviews and meetings cannot. They also allow for a variety of questions such as bio-data, self-rating, and judgmental rating (Brown, 1995). Moreover, questionnaires are useful in collecting data from a large number of people. Dudley-Evans and St John (1998) state that composing questionnaires is difficult because the words must be experimented before actual use, and they should be statistically analyzed.

NA data can also be gathered through interviews. They are used to ask open-ended questions. They permit collecting private information from individuals. This can result in real opinions (Brown, 1995). They are time-consuming; therefore, they are used as follow up to another method such as questionnaires. There should be a time limit for the interview, and it should be recorded to enable the interviewer obtain suitable information (Dudley-Evans \& St John, 1998).

According to Brown (1995), tests are essential tool for NA data collection. Regardless their purpose, tests contribute rich information on students' present proficiency, on particular problems in language, and on their attainment in past courses.

Some methodological aspects in NA should be considered. These are sources of data, triangulation, and types of data to be collected. Brown (1995), Dudley-Evans and St John (1998), and Richards (2001) agree that NA information has a number of sources. Brown (1995) classifies these sources into four groups. The first is the target group, which includes students, teachers, and administrators. The second group is the audience. This refers to the people who are required to act upon the NA result. They include course managers, supervisors, or any ruling bodies above the language course. The third is the resource group. This means people who can provide relevant information such as parents, financial sponsors, future employers, or specialization professors. The fourth group is needs analysts. These are either consultants from outside the institution or members of the institution (Robinson, 1991).

Triangulation refers to the use of more than one method of data collection as well as source of information (West, 1997; Richards, 2001; Nugraha, 2002; Long, 2005; Brown, 2009). This, according to Long (2005, p. 28), increases "credibility of...interpretations of data". Richards (2001) explains that the use of multiple sources of information can complement each other. This is because each method of data collection has strengths and weaknesses. For example, questionnaires have a low level of return, and when distributed, the questions cannot be altered. Moreover, they cannot investigate the participants' feelings in depth. Interviews, however, can cover this weakness by providing complete and deep coverage to the questions since the physical presence of the analyst.

Rossett (1982) and Brown (1995) agree that there are varieties of questions that must be asked in the NA. These include problems, priorities, abilities, attitudes, and solutions. Brown (1995) elaborates on these types of questions. He states that when asking questions about problems, the needs analysts try to identify the problems that the group under analysis are facing in learning the language. Priorities questions focus on the themes, language uses, and skills the target group regards as most important to learn. Questions may cover the main 
skills: reading, writing, listening, and speaking, or grammar. In relation to these skills, questions about which of the sub-skills are considered most important can be asked.

Questions about abilities investigate students' current abilities before starting the programme. This information is essential for it constitutes the starting point of the course. In addition, it describes the students' current level. These two points are crucial for designing the starting level, focus, and sequence of the course. Attitudes questions define the target group's feelings and attitudes to the components of the course. Questions about solutions seek to identify opinions for solving the perceived problems.

Basturkmen (2010) explains that the NA process involves asking questions about five pints. First, it asks questions about the target situation to determine the tasks, activities, and skills for which English will be used. Second, it includes discourse analysis to describe the language used in the target situation. Third, NA asks about what students can currently do or cannot do in relation to the target situation. Fourth, it analyses the learner factor. It attempts to discover information about students' motivation, how they learn, and their perception of their needs. Finally, it includes context analysis, which refers to assessing factors related to the surrounding in which the course will be run.

\section{Empirical Studies}

The study of NA is, in fact, not a new one. This section, therefore, aims at discussing related empirical research on NA in order to see each study's findings and their possible implications to be compared with the findings of the present research.

Ghenghesh (2013) conducted a NA study to identify the English language needs of undergraduate students at the Faculty of Engineering, British University in Egypt (BUE). The subjects of the study were 93 students and 26 engineering staff members. In order to collect data, the study used a questionnaire and an interview. The questionnaire was of two versions. The first was for the students. It consisted of six parts. They sought to elicit information about the students' background, importance of English, students' proficiency level, curriculum content, information about the current course book, writing section in the course book, and the number of contact hours. There was one open-ended question. The second questionnaire was administered to the engineering lecturers. It was similar to the students' questionnaire, but it contained 22 close-ended questions and two open-ended items. The study found that English language was very important to engineering students. Speaking and writing were of high priority for the participants. In addition, a variety of academic sub-skills such as reading academic texts, writing technical reports, giving oral presentation, and listening to course lectures should be incorporated in the course to motivate, engage the students and to meet their needs. Ignoring learning needs and means analysis, Ghenghesh's study only studied the target and present situations. The sample did not involve any graduate students as well as EFL/ESP teachers.

Alastal and Shuib (2012) conducted a study to investigate the academic and target needs for English of undergraduate students at the faculty of Applied Science (FAS), Al-Aqsa University (AU), Palestine. The purpose of the study was to identify the students' current proficiency, the English language skills important for their study, and the English language skills they wanted to study. The subjects were 180 students at FAS. To collect data, a questionnaire was distributed to the subjects. It contained 26 close-ended items. The questions were divided into five sections A-E. Section A asked about general information. Section B focused on the importance of English in students' field. The third section elicited information about students' current proficiency level. The fourth section, D, sought to concentrate on the skills that the students considered 
necessary and they wanted to learn. The last section asked about the appropriate English curriculum, content, and materials that should be taught to students. The study revealed that English language is important to the students of Applied Science because it is used in the teaching and learning process at FAS. In addition, it showed that the students' proficiency level was average in academic writing and reading comprehension skills, and it was weak in academic speaking and listening skills. Another finding was that the most important academic skills were reading, listening, and writing skills. Moreover, the students wanted to improve the four skills with emphasis on speaking skills. The study concluded that the current ESP course did not meet students' needs. It, therefore, recommended that students should study specific course of English for academic purposes that would meet their needs. This study has some methodological problems. It only used a questionnaire to collect data. In addition, its sample was only students. Using triangulation in data collection tools and sources of information could have provided valuable data to inform the study's findings. The study also did not cater for learning needs.

Altamimi and Shuib (2010) studied the needs of petroleum students at Hadhramout University of Science and Technology (HUST). The study aimed at identifying the petroleum-engineering students' use of the English language skills, the importance of English language skills to the students, students' English language proficiency level, and students' lacks and wants. Eighty-one third, fourth, and fifth year students were the subjects of the study. Altamimi and Shuib used a questionnaire to collect data. It contained a number of sections that focused on frequency of skills use, importance of these skills, students' lacks, students' self-rating of their abilities in English sub-skills, and students' lacks and wants. The findings revealed that English language was very important for petroleum engineering students. In addition, the study showed that writing assignments, reading course handouts, writing laboratory reports, following lectures, and reading textbooks were the most frequent used sub-skills. In terms of lacks, the study found that the students' English language proficiency was low. As far as students' wants are concerned, it discovered that students wanted to learn listening and speaking. Furthermore, the study showed that the time allotted to English language lessons was not enough to enhance students' proficiency. Although Altamimi and Shuib's study seems to be comprehensive, it has some gaps. Similar to the study of Alastal and Shuib (2012), this study did not triangulate data collection methods and source of information. It only surveyed students by using just a questionnaire. Had it used other tools in addition to the questionnaire, this would have revealed results that are more reliable. The study also neglected means analysis, which could have shown the reasons behind students' low proficiency.

Dafa-Allah (2012) investigated Sudanese medicine students' needs for English language. Three hundred students, who studied ESP at three universities, were the subjects of the study. A questionnaire was used as data collection instrument. It was divided into three sections. The first one asked about general needs for English. The second focused on academic needs. The third section was about students' job needs. The findings showed, generally, that the students needed English to listen to the radio, understanding TV programmes and films. In their academic study, students needed English for understanding lectures because English is the language of instruction. For their professional life, they needed to read job-related written materials. Dafa-Allah's study has some gaps. First, it only focused on target situation analysis. It neglected PSA, learning needs, and means analysis. Second, it did not include graduate students, employees, and subject teachers. Third, it did not recommend or suggest any ideas about how to meet those needs. 
Eltahir (2010) conducted a NA of second Year School of Business Administration students at U of K. The purpose of the study was to evaluate the ESP textbook taught to the students to determine whether it meets their needs or not. The participants were 90-second year students who were studying English as a required subject, five ESP teachers, one of them was the teacher who taught the textbook, and three business teachers. Eltahir used three instruments for collecting data. The first was a students' questionnaire. It contained nine questions. Questions 1-5 asked about the need for using English in their academic specialization. Questions 6-9 sought to discover the students' opinions about the textbook. The second data collection tool was an interview with the ESP teachers. It focused on questions about the relation between ready-made material and students' needs, the relation between the objectives of tailored material and students' needs, whether those objectives are achieved or not, and the skills which should be focused on. The third data collection method was an interview with specialization teachers. It asked five questions about students' needs for English, the skills mostly needed, and the material they could recommend to be taught to their students. The study found that the students did not need English to study their specialization, but English was needed to study business terminology. In addition, the students pointed out that the textbook (English II) was very useful since it contains business terminology. Moreover, all the subjects agreed that students' level of English needed to be improved. Eltahir's study did not involve graduate students in the participants. In addition, it did not show or recommend any ideas about how to improve students' English proficiency.

\section{Methodology}

\section{Participants}

The participants were 490 (390 in the questionnaire and 100 in the proficiency test) students at the Faculty of PEH and two professors at the Faculty. The students were from third, fourth, fifth, qualifying, and Master's students. The sample was chosen by using the strategy of systematic sampling arranged by class. This strategy of sample selection was used since it is the most suitable one for this research. It is easy to create and more accurate than a simple random sample. It involves stratification that minimizes sampling errors to zero level (Alastal \& Shuib, 2012; Long, 2005).

The reasons for excluding first and second year students were that, on one hand, they were still in the beginning of their university study, and they could not form a clear idea about their needs for English language (Alastal \& Shuib, 2012). On the other hand, the selected groups experienced studying both English language and their specialization subjects. Therefore, it is assumed that they have enough experience to determine the importance and need for English language.

\section{Instruments}

To collect data, the study used three instruments to triangulate data collection. The first was a questionnaire for PEH undergraduate students. The second instrument was a proficiency test for the undergraduates. The third one was an interview with two programme coordinators.

The questionnaire was designed after reviewing a number of studies and previous questionnaires such as Alastal and Shuib (2012), Alqahtani (2011), Ali (2011), Alhuqbani (2008), Richards (2001), and Chan (2000). These questionnaires were consulted for design, content, and layout. The questionnaire was divided into five sections. Section A sought to collect background information about the participants (items 1-3). Section B collected information about the purposes for needing English language (items 5-8). Section C focused on 
students' present situation where items (9-16) asked students to rate their proficiency in English language. Items 17-23 sought to identify the problems students faced in learning English language. The fourth section, D, concentrated on skills, grammar, vocabulary, and pronunciation importance. Items 24-31 dealt with the four macro skills and items 32-62 covered the micro skills regarding reading, writing, speaking, and listening, respectively. The last section, E, attempted to analyze students' learning needs. Items $63-77$ asked about the preferred classroom activities, items 78-81 focused on the role of the teacher and students in the classroom, and items 82-84 asked about the time for the ESP course.

To check PEH students' current level of English language, a proficiency test was used. The test was adapted from the one designed by Abdellah and Ibrahim (2013). It contained five sections. These sections covered grammar and vocabulary, reading, writing (both guided and free writing), listening, and speaking. The grammar and reading questions were mainly MCQs. Listening questions were true and false. For speaking, students were asked to give information about themselves and describe a photo that they selected form a group of photos.

The interview contained eight questions. Questions 1-4 asked about students' needs for English language, the purposes for which they needed English, the tasks they needed to do in English, the importance of skills for students as perceived by the participants. Items 5-6 focused on the participants' opinion on students' current level of English and the problems they had in learning and using English. Questions 7-8 tried to identify the suitability of the time given to the English course, and suggestions for meeting students' needs.

\section{Reliability}

Dornyei (2003) contends that reliability is the measurement of the degree to which the scores on the data collection tool are free of errors. In this case, the method used to measure reliability is internal consistency. It can be measured by the Cronbach Alpha coefficient, which ranges between zero and one. To have acceptable reliability, instruments need to score at least 0.60 (Dornyei, 2003). To calculate the instruments reliability, SPSS version 21 was used to obtain the Cronbach Alpha. After that, the Square Root (Sqrt) of the value of Cronbach Alpha was found. Table 1 below shows the instruments reliability.

Table 1

Instruments Reliability

\begin{tabular}{llll}
\hline Instrument & Cronbach's alpha & No. of items & Reliability (Sqrt. of Cronbach's alpha) \\
\hline Students' questionnaire & .850 & 125 & 0.92 \\
Proficiency test & .613 & 6 & 0.78 \\
\hline
\end{tabular}

Taking in consideration that the acceptable reliability should be at least 0.60 , it can be concluded that the two instruments shown in Table 1 above are reliable.

\section{Procedures}

Data collection started on 3/6/2013 to 10/6/2103. A permission was obtained from the Dean of the Faculty. Students were informed of the objectives of the questionnaire and confidentiality was confirmed. Since the researcher taught the majority of the students in their first year, students were enthusiastic to participate in the study. The proficiency test was held on 19/1/2014 and it lasted for two working days due to the speaking section. Two volunteers from Sudan Volunteer Programme (SVP) conducted the speaking test. 


\section{Results and Discussion}

This section presents the results and their discussion. It is organised to cover the purposes for which students need English language, students' present situation in English language, the main four skills and sub skills importance, and students' learning needs. These represent the research questions.

\section{The Need for English and Purposes for Needing it}

Question 4 in the students' questionnaire sought to determine the need for English language. The need for English is also covered by question 1 in the interview. Table 2 below summarizes the questionnaire results.

Table 2

PEH Students Needs for English Language as Perceived by the Students

\begin{tabular}{lll}
\hline Response & No. & $\%$ \\
\hline Yes & 384 & 98.5 \\
No & 6 & 1.5 \\
Total & 390100 & 100 \\
\hline
\end{tabular}

From the table above, it is obvious that almost all the subjects, $384(98.5 \%)$ of the students agreed that they needed English language. Similarly, the two interviewees confirmed that their students needed English language. The purposes for which PEH students need English language are covered in the questionnaire and the interview. Figure 1 below shows the results.

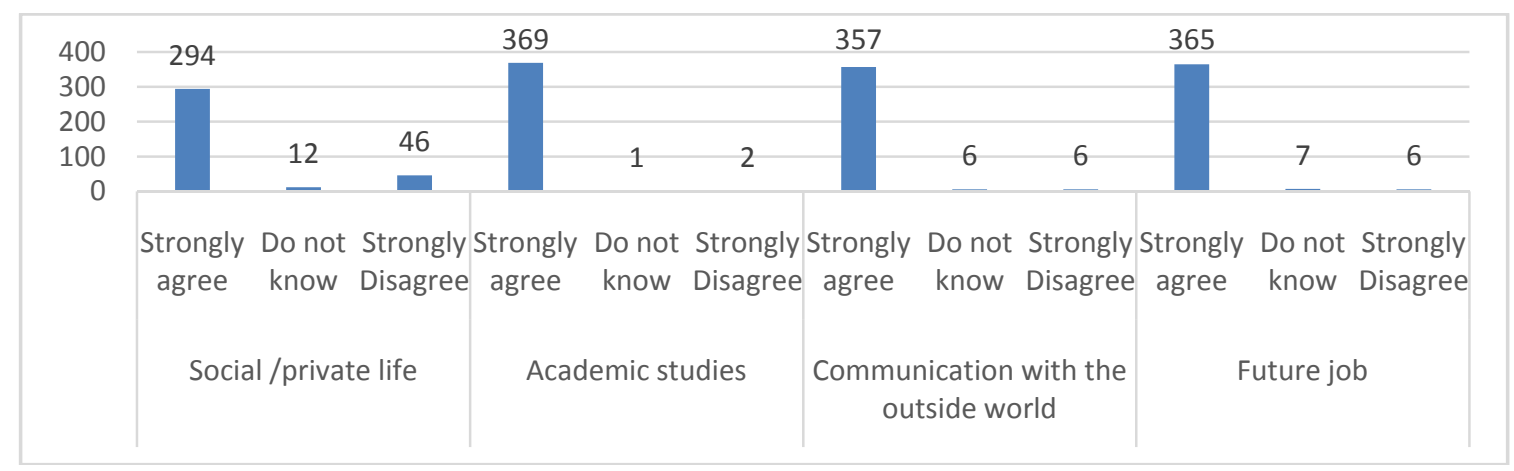

Figure 1. Purposes for needing English language as perceived by students.

The figure shows that PEH students mainly needed English for academic studies 369 (94.6\%), future job 365 (93.6\%), and communication with the outside world 357 (91.5\%). It seems that students were fully aware of the importance of English for academic studies. They indicated that it is important for academic study despite that fact that it is not the official language of teaching at the Faculty of PEH in the undergraduate programme, but it is the teaching language in the postgraduate programmes. As for social private life, English was not needed because English is not used in everyday life in Sudan. This result connotes that students are aware of the importance of English language to both their academic study and future job. According to Hutchinson and Waters (1987), most of English language learners are mindful of the purpose for which they learn the language.

Questions 2-3 in the interview covered the purposes for which students need English. The questions asked about the purposes for needing English and the tasks students need to do using English, respectively. For the second question, the two interviewees agreed that PEH students needed English for academic study. The AUR 
coordinator added that students needed English for future job as it enables them to get a good job. As for the third question, they agreed that students needed to read references written in English, write research, especially for 5th year and Master's students, and communicate with the outside world.

The results imply that English is important to PEH students. They also indicate that PEH students and staff are aware of the needs for English language. These results are consistent with the findings of Dafa-Alla (2012), Alastal and Shuib (2012), and Altamimi and Shuib (2010) who concluded that their participants indicated that they needed English language. A number of studies revealed the need for English language for academic purposes, future job, and communication with the outside world and this study confirms their findings. Alastal and Shuib (2012) found that undergraduate students of Faculty of Applied Science, Al-Aqsa University, needed English for academic purposes because it is the language of instruction in the Faculty. They also found that students needed English for future profession. Dafa-Allah (2012) revealed the same results. Eltahir (2010) concluded that his students needed English for academic purposes. However, these results contradict with those of Ghenghesh (2013) who found that students needed English only for their future work.

\section{Students' Present Situation in English Language}

Section C in students' questionnaire asked students to rate themselves in the four skills in addition to grammar, general vocabulary, scientific vocabulary, and pronunciation. The results are summed up in Table 3 below.

Table 3

Students' Self-rating in the Four Skills and Other Language Areas

\begin{tabular}{|c|c|c|c|c|c|c|c|c|c|}
\hline \multirow{2}{*}{ No. } & \multirow{2}{*}{ Lang. skills/ areas } & \multicolumn{2}{|c|}{ Good } & \multicolumn{2}{|c|}{ Average } & \multicolumn{2}{|c|}{ Weak } & \multicolumn{2}{|c|}{ Total } \\
\hline & & No. & $\%$ & No. & $\%$ & No. & $\%$ & No. & $\%$ \\
\hline 9 & Reading skills & 272 & 70.1 & 91 & 23.5 & 25 & 6.4 & 388 & 100 \\
\hline 10 & Writing skills & 242 & 62.2 & 99 & 25.4 & 48 & 12.4 & 389 & 100 \\
\hline 11 & Speaking skills & 153 & 39.6 & 122 & 31.5 & 112 & 29.0 & 387 & 100 \\
\hline 12 & Listening skills & 226 & 58.9 & 105 & 27.3 & 53 & 13.6 & 384 & 100 \\
\hline 13 & General vocabulary & 228 & 59.3 & 108 & 28.1 & 49 & 12.7 & 385 & 100 \\
\hline 14 & Scientific vocabulary & 191 & 49.6 & 133 & 34.5 & 61 & 15.9 & 385 & 100 \\
\hline 15 & Grammar & 227 & 59.0 & 103 & 26.8 & 54 & 14.1 & 385 & 100 \\
\hline 16 & Pronunciation & 192 & 49.5 & 125 & 32.2 & 71 & 18.3 & 388 & 100 \\
\hline
\end{tabular}

As seen in Table 3, big numbers of students that ranged between 226 and 272 (58.9-70.1\%) rated themselves as good in the language skills and areas provided. At the top comes reading skills $272(70.1 \%)$, and writing skills $242(62.2 \%)$. They were followed by general vocabulary, grammar, and listening skills.

The interview contained a question that asked the interviewees about their perception of their students' standard in English language. The Master's programme coordinator stated that undergraduate students were weak at English language. He divided the Master's students into two groups. The first one was good to very good because the students studied in English in their undergraduate programme. These students were from faculties of Medicine and other universities where the medium of instruction is English. The second group of students was weak at English language because they studied in Arabic language-PEH students. The AUR coordinator considered the students as week at English language.

To reveal the students' real level of English language, a proficiency test was administered. As it is clear from Table 4 below, the students' level is below average $M=24.14$. 
Table 4

Mean and Standard Deviation of PEH Students' Scores in the Proficiency Test

\begin{tabular}{llll}
\hline Section & Total score & Mean & SD \\
\hline Grammar & 10 & 4.70 & 2.81 \\
Reading & 15 & 6.71 & 3.27 \\
Writing A & 5 & 2.82 & 1.91 \\
Writing B & 10 & 2.82 & 1.61 \\
Listening & 10 & 4.08 & 2.41 \\
Speaking & 10 & 2.90 & 1.21 \\
Total & 60 & 24.12 & 8.01 \\
\hline
\end{tabular}

The table shows that the students were below average in all the skills and grammar except reading (6.71). They were weak in writing $(M=2.82)$, speaking $(M=2.92)$, grammar $(M=4.70)$, and listening $(M=4.08)$. As for writing, they could not write correct sentences. Most of the sentences were fragments, and they showed that they had a problem in subject verb agreement. Their ideas were unorganised, and they did not know how to use the punctuation marks. They misused many words in terms of word form. Besides, they could not spell words correctly. When speaking, they could not express themselves even in a single sentence. Their pronunciation was unclear and most of it was wrong. This was probably because of lack of practice. They are not familiar to speaking English. As for grammar, despite the fact that they studied a lot of grammar in their previous study of English, they were weak in it. They could not use it correctly when writing and speaking. In listening, students were also weak because most of them were not familiar to it during studying English language. It is shown in the table above that the mean score for listening is (4.08) and for grammar is (4.70) which are relatively higher than speaking and writing. This can be attributed to the type of questions, MCQs, used in the test. Chance may have played a role in choosing the correct answer. As for reading, students' score is 6.71 that is the highest mean. This is because students had lots of training in reading in secondary school. In addition, the questions in the test only required direct answer from the text. No question needed higher level of thinking was included in the questions.

It is obvious that there was a discrepancy regarding $\mathrm{PEH}$ students' level of English language. PEH students regarded themselves as good to average, but the proficiency test showed that the students were weak in almost all the skills. This is an indication that students were not aware of their real standard in English language. This weakness in English can be attributed to the teaching of English in general education where students' goal was to pass examinations. The SPINE series, which is used to teach English in Basic and Secondary levels, focuses only on reading and grammar and it does not cater for listening, speaking, and writing. Another reason behind this weakness is the use of Arabic as a medium of instruction at universities. This leads to neglecting English language. This was confirmed by the Master's programme coordinator, who stated that students who studied in faculties that teach through English language were very good to good at English. It is clear that PEH students needed English language, but they were weak at it. This constitutes a problem to the students, Faculty of PEH, and the English Department at the AUR. They should solve this problem by trying to improve the students' level of English.

These findings correspond to what was revealed by Genghesh (2013) who found that undergraduate students of Engineering at the British University in Egypt were satisfied with their level of proficiency. Unlike the findings of this research, Altamimi and Shuib (2010) found that their students were average in writing, 
reading, vocabulary, and grammar, and they were weak at listening, speaking, and communication skills. It appears that weak proficiency in English language is not only a problem for Sudanese EFL learners, but it is also a problem for many other students outside Sudan as suggested by the results mentioned above. In Summary, it can be concluded that PEH students need English language despite their weak level at it.

Items 17-23 in the students' questionnaire asked the participants about the difficulties they faced when learning English. The results are presented in Table 5 below.

Table 5

Students' Difficulties in Learning English

\begin{tabular}{|c|c|c|c|c|c|c|c|c|c|}
\hline \multirow{2}{*}{ No. } & \multirow{2}{*}{ Problem } & \multicolumn{2}{|c|}{ Yes } & \multicolumn{2}{|c|}{ No } & \multicolumn{2}{|c|}{ Do not know } & \multicolumn{2}{|c|}{ Total } \\
\hline & & No. & $\%$ & No. & $\%$ & No. & $\%$ & No. & $\%$ \\
\hline 25 & Limited vocabulary & 278 & 72.6 & 87 & 22.7 & 18 & 4.7 & 383 & 100 \\
\hline 26 & Grammar & 200 & 52.9 & 164 & 43.4 & 14 & 3.7 & 378 & 100 \\
\hline 27 & Reading comprehension skills & 198 & 52.4 & 166 & 43.9 & 14 & 3.7 & 378 & 100 \\
\hline 28 & Writing skills & 168 & 44.7 & 197 & 52.4 & 11 & 2.8 & 376 & 100 \\
\hline 29 & Speaking skills & 282 & 74.0 & 83 & 21.8 & 16 & 4.2 & 381 & 100 \\
\hline 30 & Listening skills & 183 & 48.4 & 185 & 48.9 & 10 & 2.6 & 378 & 100 \\
\hline 31 & Correct pronunciation & 244 & 63.9 & 123 & 32.2 & 15 & 3.9 & 382 & 100 \\
\hline
\end{tabular}

From the Table 5 above, students found almost all the skills difficult especially speaking 282 (74.0\%), limited vocabulary $278(72.6 \%)$, correct pronunciation $244(63.9 \%)$, grammar $200(52.9 \%)$, and reading comprehension skills 200 (52.4\%). However, students considered that writing was not a problem for them 197 (52.4\%). This result contradicts with the finding of the proficiency test. The proficiency test showed that students' weakest skill was writing. They also stated that listening was not a problem, but from the test result, listening was another problem that faced them. It is worth noting that students rated themselves as good to average in these skills; nevertheless, they faced difficulties in learning them. Students found speaking as the most difficult skill in learning English because of lack of situations where they can use English language, which is a foreign language in Sudan. Therefore, it is not used outside classrooms. Students lack opportunities to practice English.

In the interview, question six asked about students' problems when using English language. The Master's coordinator explained that students could not understand spoken English in lectures, and they did not understand the references they read in English. They could not express themselves when answering examination questions. To solve these problems, he suggested adopting English language as the language of instruction in the faculty. The AUR coordinator stated that students had problems in vocabulary, spelling, writing, and speaking. Consequently, they avoided using English language during lectures, and they felt uncomfortable when it is used in teaching them. The results imply that the previous course which PEH students studied was not effective. It did not cater for students' needs and it did not raise their proficiency. This calls for a syllabus that meets their needs and improves their English language. These results indicate that there is a problem in basic and secondary school English language curriculum and/or the teaching of English in these two levels. These findings accord with what was revealed by Altamim and Shuib (2010) who found that all the four skills were difficult for their subjects.

\section{Skills Importance}

Skills importance is included in the students' questionnaire (items 24-31). Table 6 displays the results. 
The table shows that PEH students regarded speaking skill as the first in importance since all the participants $390(100 \%)$ agreed on that. It is followed by reading skills $385(99.7 \%)$, writing skills $383(99.5 \%)$, and listening skills 380 (99.2\%). Students also considered pronunciation 378 (99.2\%), and scientific vocabulary 377 (99.4\%) as very important. Thus, PEH students considered that the order of skills importance as speaking, reading, writing, and listening. These were followed by pronunciation 378 (99.2\%), scientific vocabulary 377 (99.4\%), general vocabulary $375(99.1 \%)$, and grammar $370(97.3 \%)$.

Table 6

Skills Importance as Perceived by Students

\begin{tabular}{|c|c|c|c|c|c|c|c|c|c|}
\hline \multirow{2}{*}{ No. } & \multirow{2}{*}{ Skills } & \multicolumn{2}{|c|}{ V. Important } & \multicolumn{2}{|c|}{ Unimportant } & \multicolumn{2}{|c|}{ Do not know } & \multicolumn{2}{|c|}{ Total } \\
\hline & & No. & $\%$ & No. & $\%$ & No. & $\%$ & No. & $\%$ \\
\hline 24 & Reading skills & 385 & 99.7 & 1 & 0.3 & & & 386 & 100 \\
\hline 25 & Writing skills & 383 & 99.5 & 2 & 0.5 & & & 385 & 100 \\
\hline 26 & Speaking skills & 390 & 100 & & & & & 390 & 100 \\
\hline 27 & Listening skills & 380 & 99.2 & 2 & 0.5 & 1 & 0.3 & 383 & 100 \\
\hline 28 & General vocabulary & 375 & 99.1 & 2 & 0.5 & 1 & 0.3 & 378 & 100 \\
\hline 29 & Scientific vocabulary & 377 & 99.4 & 1 & 0.3 & 1 & 0.3 & 379 & 100 \\
\hline 30 & Grammar & 370 & 97.3 & 6 & 1.6 & 4 & 1.1 & 380 & 100 \\
\hline 31 & Pronunciation & 378 & 99.2 & 2 & 0.5 & 1 & 0.5 & 381 & 100 \\
\hline
\end{tabular}

It can be stated that all the four skills were considered very important in addition to vocabulary, grammar and pronunciation. As for speaking, it is seen as the most important one; thus, this represents students" "wants". Hutchinson and Waters (1987, p. 56) suggest that wants may vary form needs and contradict with the perception of other stakeholders. Reading was also considered very important. This is an indication that students were aware of the importance of this skill for their academic study because the majority of the scientific books in their field are written in English. Writing was very important as well since students needed to write their graduation projects and Master's theses in English. This requires intensive training on these two skills. It is normal to find difficulty in discovering students' needs when, theoretically, students need to read, but they may be interested in other skills "delayed needs rather than immediate needs" (Dudley-Evans \& St. John, 1998, p. 40). In addition, Robinson (1991, p. 105) believes that many students think that speaking is a measurement to the mastery of the language. Thus, all the four skills were important to PEH students, but priority is for reading and writing. These findings are consistent with what was found by Ghenghesh (2013) who revealed that the importance of the skills was as follows: speaking, writing, reading, and listening. Alastal and Shuib (2012) found these skills important in the following order listening, reading, writing, and speaking.

Similarly, the students' questionnaire asked the participants about the importance of some sub skills. These sub skills are related to reading, writing, speaking, and listening. For reading sub skills, Table 7 shows the students' response. They regarded as the most important sub skills the following: reading their specialisation textbooks and scientific articles 376 (98.4\%), understanding main points of a text $353(97.5 \%)$, understanding vocabulary from a text $352(96.2 \%)$, reading course hand-outs $365(96.1 \%)$, and reading to find specific information 352 (93.4\%). 
Table 7

Sub Skills Importance as Perceived by Students: Reading

\begin{tabular}{|c|c|c|c|c|c|c|c|c|c|}
\hline \multirow[t]{2}{*}{ No. } & \multirow[t]{2}{*}{ Item } & \multicolumn{2}{|c|}{ Strongly agree } & \multicolumn{2}{|c|}{ Do not know } & \multicolumn{2}{|c|}{ Strongly disagree } & \multicolumn{2}{|c|}{ Total } \\
\hline & & No. & $\%$ & No. & $\%$ & No. & $\%$ & No. & $\%$ \\
\hline 32 & $\begin{array}{l}\text { Reading your specialisation textbooks and scientific } \\
\text { articles }\end{array}$ & 376 & 98.4 & 4 & 0.1 & 2 & 0.5 & 382 & 100 \\
\hline 33 & Reading to find specific information in a textbook & 352 & 93.4 & 18 & 4.8 & 1 & 0.5 & 377 & 100 \\
\hline 34 & Reading course hand outs & 365 & 96.1 & 9 & 2.4 & 6 & 1.6 & 380 & 100 \\
\hline 35 & Reading texts from the internet & 358 & 79.5 & 12 & 3.2 & 7 & 1.9 & 377 & 100 \\
\hline 36 & Reading extra references & 336 & 89.6 & 25 & 6.7 & 14 & 3.7 & 375 & 100 \\
\hline 37 & Understanding vocabulary from the context & 352 & 96.2 & 10 & 2.7 & 4 & 1.0 & 366 & 100 \\
\hline 38 & Understanding main points of text & 353 & 97.5 & 8 & 2.2 & 1 & 0.3 & 362 & 100 \\
\hline 39 & Others & & & & & & & & \\
\hline
\end{tabular}

It is also noticeable that the participants in spite of their agreement on the sub skills importance, their ordering to this importance was different. They considered one sub skill as more important than the other. This might be caused by a particular group perception of the needs.

Concerning writing sub skills, the students ranked using appropriate vocabulary 353 (97.2\%), using suitable style 346 (96.9\%), writing correct sentences 350 (96.7\%), writing well-structured paragraphs 349 (954\%), organising and planning writing 337 (93.6\%), developing ideas $336(94.1 \%)$, and writing summary and paraphrasing $336(93.1 \%)$ as the most important writing sub skills (see Table 8 below).

Table 8

Sub Skills Importance as Perceived by Students: Writing

\begin{tabular}{llllllllll}
\hline \multirow{2}{*}{ No. } & Item & \multicolumn{3}{c}{ Strongly agree } & \multicolumn{2}{c}{ Do not know } & \multicolumn{2}{c}{ Strongly disagree } & \multicolumn{2}{c}{ Total } \\
\cline { 3 - 9 } & & No. & $\%$ & No. & $\%$ & No. & $\%$ & No. & $\%$ \\
\hline 40 & Writing correct sentences & 350 & 96.7 & 8 & 2.2 & 4 & 1.1 & 362 & 100 \\
41 & Writing well-structured paragraphs & 349 & 95.4 & 11 & 0.3 & 6 & 1.6 & 366 & 100 \\
42 & Writing lab report & 316 & 87.3 & 29 & 8.0 & 17 & 4.7 & 362 & 100 \\
43 & Writing research or report & 329 & 91.6 & 19 & 5.4 & 11 & 3.0 & 359 & 100 \\
44 & Writing summary and paraphrasing & 336 & 93.1 & 19 & 5.3 & 6 & 1.7 & 361 & 100 \\
45 & Organizing and planning writing & 337 & 93.6 & 16 & 4.4 & 7 & 1.9 & 360 & 100 \\
46 & Developing ideas & 336 & 94.1 & 16 & 4.5 & 5 & 1.4 & 357 & 100 \\
47 & Using correct punctuation and spelling & 326 & 92.6 & 13 & 3.7 & 13 & 3.7 & 352 & 100 \\
48 & Using appropriate vocabulary & 353 & 97.2 & 8 & 2.2 & 2 & 0.6 & 363 & 100 \\
49 & Using suitable style & 346 & 96.9 & 9 & 2.5 & 2 & 0.6 & 357 & 100 \\
50 & Evaluating and revising writing & 334 & 93.0 & 14 & 3.9 & 11 & 3.0 & 359 & 100 \\
\hline
\end{tabular}

This confirms, particularly, the importance of reading and writing to students' academic study. This indicates that students were aware of the English language macro and micro skills importance despite the fact that English is not formally used in teaching at the Faculty at the undergraduate level.

As for speaking and listening, the students regarded asking for information 315 (97.2\%), pronouncing word correctly 349 (96.4\%), and asking and answering questions 346 (95.9\%) as the most important speaking sub skills, Table 9. For listening sub skills, as Table 10 shows, the students stated that listening to lectures 366 (96.3\%), listening to conversation on general/specific topics $344(96.3 \%)$, and listening to get specific information 341 (95.0\%) were the most important listening sub skills. 
Table 9

Sub skills Importance as Perceived by Students: Speaking

\begin{tabular}{llllllllll}
\hline \multirow{2}{*}{ No. } & Item & \multicolumn{3}{c}{ Strongly agree } & \multicolumn{3}{c}{ Do not know } & \multicolumn{3}{c}{ Strongly disagree } & Total \\
\cline { 3 - 9 } & & No. & $\%$ & No. & $\%$ & No. & $\%$ & No. & $\%$ \\
\hline 52 & Pronouncing words correctly & 349 & 96.4 & 9 & 2.5 & 4 & 1.1 & 362 & 100 \\
53 & Asking and answering questions & 346 & 95.9 & 12 & 3.3 & 3 & 0.8 & 361 & 100 \\
54 & Asking for information & 351 & 97.2 & 5 & 1.4 & 5 & 1.4 & 361 & 100 \\
55 & Participating in academic/ & 333 & 92.5 & 14 & 3.9 & 13 & 3.6 & 358 & 100 \\
56 & professional discussion & 331 & 92.5 & 14 & 3.9 & 13 & 3.6 & 358 & 100 \\
57 & Giving presentations & & & & & & & & \\
\hline
\end{tabular}

Table 10

Sub Skills Importance as Perceived by Students: Listening

\begin{tabular}{|c|c|c|c|c|c|c|c|c|c|}
\hline \multirow[t]{2}{*}{ No. } & \multirow[t]{2}{*}{ Item } & \multicolumn{2}{|c|}{ Strongly agree } & \multicolumn{2}{|c|}{ Do not Know } & \multicolumn{2}{|c|}{ Strongly disagree } & \multicolumn{2}{|c|}{ Total } \\
\hline & & No. & $\%$ & No. & $\%$ & No. & $\%$ & No. & $\%$ \\
\hline 58 & Listening to lectures & 366 & 96.3 & 9 & 2.5 & 4 & 1.2 & 357 & 100 \\
\hline 59 & $\begin{array}{l}\text { Listening to conversations on general } \\
\text { and/or specific topics }\end{array}$ & 344 & 96.3 & 9 & 2.5 & 4 & 1.2 & 357 & 100 \\
\hline 60 & Listening to English media & 331 & 92.8 & 13 & 3.6 & 13 & 3.6 & 357 & 100 \\
\hline 61 & Listening to get specific information & 341 & 95.0 & 9 & 2.5 & 9 & 2.5 & 359 & 100 \\
\hline 62 & Others & & & & & & & & \\
\hline
\end{tabular}

It can be noticed that these sub skills contain product skills such as writing correct sentences and pronouncing words correctly, which are of great importance to both writing and speaking. It is sometimes important to pay attention to product rather than process. All these sub skills were considered as important. This implies that the participants take the issue of English language skills seriously and they want to have a good level of proficiency. The results also indicate that any new ESP course must attempt to meet these needs by including at least some of these sub skills. In the questionnaire, a question asked the participants to add any other sub skills not included in the questionnaire. All the participants did not suggest any other sub skills. This may be because they do not know what sub skills to add.

In the interview, question four asked the interviewees about the importance of the skills to their students. The two participants indicated that all the four skills were important to students. The Master's coordinator emphasised that reading and writing were priorities followed by listening. The AUR coordinator stated that PEH students should master all the skills for their future. These findings confirm the contradiction represented by students "wants" (priority to speaking) and staff's perception (priority to reading, writing, and listening). This implies that the proposed course must consider this contradiction by trying to meet both views. These findings agree with what was revealed by Ghenghesh (2013), Alastal and Shuib (2012), and Dafa-Allah (2012). They found that their participants agreed on the importance of almost all the sub-skills.

\section{Learning Needs}

Learning needs (LN) refers to what students need to do in order to learn the language. According to Hutchinson and Waters (1987, p. 61), an influential needs analysis should cater for students' preference to learn and the learning situation. Thus, the students' questionnaire covered learning needs. Students were asked about the activities to be included in the new course (items 63-75). Table 11 below shows the results. 
Table 11

Activities Preferred by the Students

\begin{tabular}{|c|c|c|c|c|c|c|c|c|c|}
\hline \multirow{2}{*}{ No. } & \multirow{2}{*}{ Activity } & \multicolumn{2}{|c|}{ Strongly agree } & \multicolumn{2}{|c|}{ Do not know } & \multicolumn{2}{|c|}{ Strongly disagree } & \multicolumn{2}{|c|}{ Total } \\
\hline & & No. & $\%$ & No. & $\%$ & No. & $\%$ & No. & $\%$ \\
\hline 63 & Role-plays. & 281 & 74.9 & 55 & 14.7 & 39 & 10.4 & 375 & 100 \\
\hline 64 & Simulations. & 236 & 63.4 & 59 & 15.9 & 77 & 20.7 & 372 & 100 \\
\hline 65 & Discussions & 371 & 97.4 & 9 & 2.4 & 1 & 0.3 & 381 & 100 \\
\hline 66 & Matching. & 362 & 96.3 & 10 & 2.7 & 4 & 1.1 & 376 & 100 \\
\hline 67 & Gap filling. & 277 & 74.3 & 42 & 11.3 & 54 & 14.5 & 373 & 100 \\
\hline 68 & $\begin{array}{l}\text { Open ended reading comprehension } \\
\text { questions. }\end{array}$ & 351 & 93.6 & 13 & 3.5 & 11 & 3.0 & 375 & 100 \\
\hline 69 & Multiple-choice questions. & 309 & 83.3 & 33 & 8.9 & 29 & 7.8 & 371 & 100 \\
\hline 70 & True/ false questions. & 306 & 82.0 & 22 & 5.9 & 45 & 12.1 & 373 & 100 \\
\hline 71 & Writing paragraphs & 336 & 90.4 & 15 & 4.0 & 21 & 5.6 & 372 & 100 \\
\hline 72 & Writing summary and paraphrasing & 349 & 92.3 & 14 & 3.7 & 15 & 4.0 & 378 & 100 \\
\hline 73 & Writing essays & 324 & 86.4 & 14 & 3.7 & 37 & 9.9 & 375 & 100 \\
\hline 74 & Translation of texts into English. & 352 & 92.9 & 9 & 2.4 & 18 & 4.7 & 380 & 100 \\
\hline 75 & Translation of texts into Arabic. & 296 & 79.4 & 6 & 1.6 & 71 & 19.0 & 373 & 100 \\
\hline
\end{tabular}

From the table above, it is obvious that the participants preferred a variety of activities such as discussions 371 (97.4\%), matching $362(96.3 \%)$, open-ended comprehension questions 351 (93.6\%), translation of texts into English 352 (92.9\%), writing summary and paraphrasing 349 (92.3\%), and writing paragraphs 336 (90.4\%). It can be inferred that students favoured certain types of tasks to help them learn English language. This can be attributed to the reason that they may be familiar to these tasks. In addition, this variety of activities means that students were motivated to learn English language using various types of activities. It is worth noting that including these activities makes ESP courses interesting for the students. Students were also asked to indicate their preference when studying during activities. Figure 2 below shows the results.

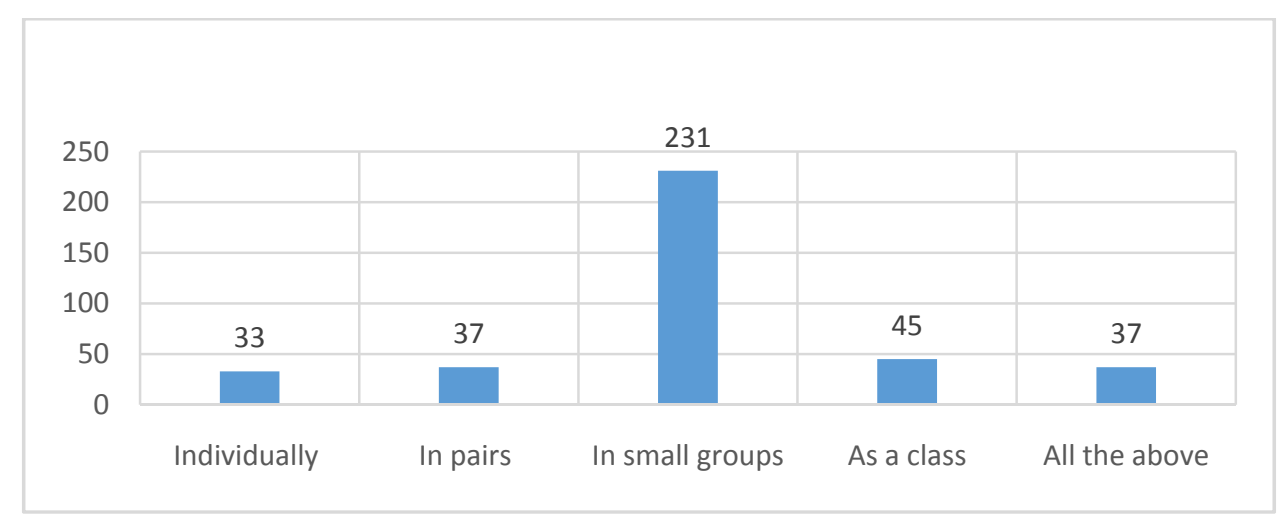

Figure 2. Students' preference in performing activities.

The figure shows that $231(60.3 \%)$ of the students preferred to do the activities in small groups. This mood of learning is useful particularly in large classes since it enables big numbers of students to practice the language simultaneously. It also assists students to learn from each other. Moreover, group work minimizes teacher talk time and increases students talk time. It can also be stated that students lack this type of learning mood in their field lectures. 
Students were asked about how the liked to learn during the English language lesson (item 77). A big number of students $243(83.5 \%)$ stated that they liked learning using audio-visual aids and $180(74.4 \%)$ by ICT. Table 12 below sums up the results.

Table 12

Students Method of Learning Preference

\begin{tabular}{lll}
\hline Item & No. & $\%$ \\
\hline Memorizing & 142 & 64.8 \\
Problem solving & 99 & 53.2 \\
Getting information on my own & 107 & 56.9 \\
Copying from the board & 78 & 45.6 \\
Audio-visual aids & 243 & 83.5 \\
ICT & 180 & 74.4 \\
Project works & 83 & 47.4 \\
All the above & 73 & 43.5 \\
\hline
\end{tabular}

It seems that students were accustomed to be taught through multimedia projector, and they may have found that interesting and motivating to be used in the English language lessons. As for the use of ICT, a rapidly growing field, there is an agreement on its effectiveness in teaching/learning generally and specifically in English language. This implies that students were aware of the importance and usefulness of audio-visual aids and ICT in teaching and learning English. ICT can be used to promote learners' autonomy and encourage students to depend on themselves in learning English. These results accord with those of Altamimi and Shuib (2012). They concluded that their students preferred to learn English using various tasks. These tasks included pair/group work, use of ICT, role play among others.

Items 78-81 asked students about their roles in the classroom compared to the teacher's during the English language lesson. From Table 13 below, it can be seen that $366(97.6 \%)$ of the participants strongly agreed that they preferred to actively participate in the activities. They 281 (76\%) also strongly agreed that the teacher should be a facilitator who helps and guides students to learn and does not control everything. These findings indicate that students really wanted to learn English depending on themselves. Their preference of the teacher to be a facilitator implies that they did not like the English class to be like their other subjects.

Table 13

Students' Preference of Classroom Interaction

\begin{tabular}{|c|c|c|c|c|c|c|c|c|c|}
\hline \multirow{2}{*}{ No. } & \multirow{2}{*}{ Item } & \multicolumn{2}{|c|}{ Strongly agree } & \multicolumn{2}{|c|}{ Do not know } & \multicolumn{2}{|c|}{ Strongly disagree } & \multicolumn{2}{|c|}{ Total } \\
\hline & & No. & $\%$ & No. & $\%$ & No. & $\%$ & No. & $\%$ \\
\hline 90 & The teacher just talks and students listen. & 214 & 60.3 & 11 & 3.2 & 130 & 36.3 & 355 & 100 \\
\hline 91 & Students actively participate in activities. & 366 & 97.6 & 2 & 0.5 & 7 & 1.9 & 375 & 100 \\
\hline 92 & The teacher controls everything. & 107 & 30.4 & 28 & 8.0 & 217 & 61.6 & 352 & 100 \\
\hline 93 & $\begin{array}{l}\text { The teacher does not control everything, } \\
\text { but helps and guides students to learn. }\end{array}$ & 281 & 76.0 & 20 & 5.4 & 69 & 18.6 & 370 & 100 \\
\hline
\end{tabular}

As for means analysis, items 85-87 in students' questionnaire asked them about the suitable number of semesters for the English language course, the appropriate number of credit hours per week, and students' number in the classroom. Tables 14 and 15 show the results. 
Table 14

The Suitable Number of Semesters for the English Language Course

\begin{tabular}{lll}
\hline No. of hours & & \\
\hline & No. & $\%$ \\
\hline $1-2$ & 28 & 9.8 \\
$3-10$ & 257 & 90.2 \\
Total & 285 & 100 \\
\hline
\end{tabular}

Table 14 shows that the majority of the students 257 (90.2\%) believed that the most suitable number of semesters for the English language course was more than two semesters. Currently, students study English only for two semesters, and it seems that the students were not satisfied with that. Concerning the suitable number of credit hours, the results are shown in Table 15 below.

Table 15

The Suitable Number of Credit Hours for the English Language Course

\begin{tabular}{lll}
\hline No. of hours & & \\
\hline & No. & $\%$ \\
\hline 2 & 82 & 21.4 \\
$4-8$ & 301 & 77.8 \\
Total & 383 & 100 \\
\hline
\end{tabular}

It is clear from Table 15 that $301(78.6 \%)$ of the students considered that two hours a week were not enough for learning English. It appeared that choosing participants from third to fifth year in the faculty of PEH to participate in this study was useful in providing information of value to the study. Students believed that the course they studied in two semesters, for two hours a week, was not enough to raise their proficiency in English language.

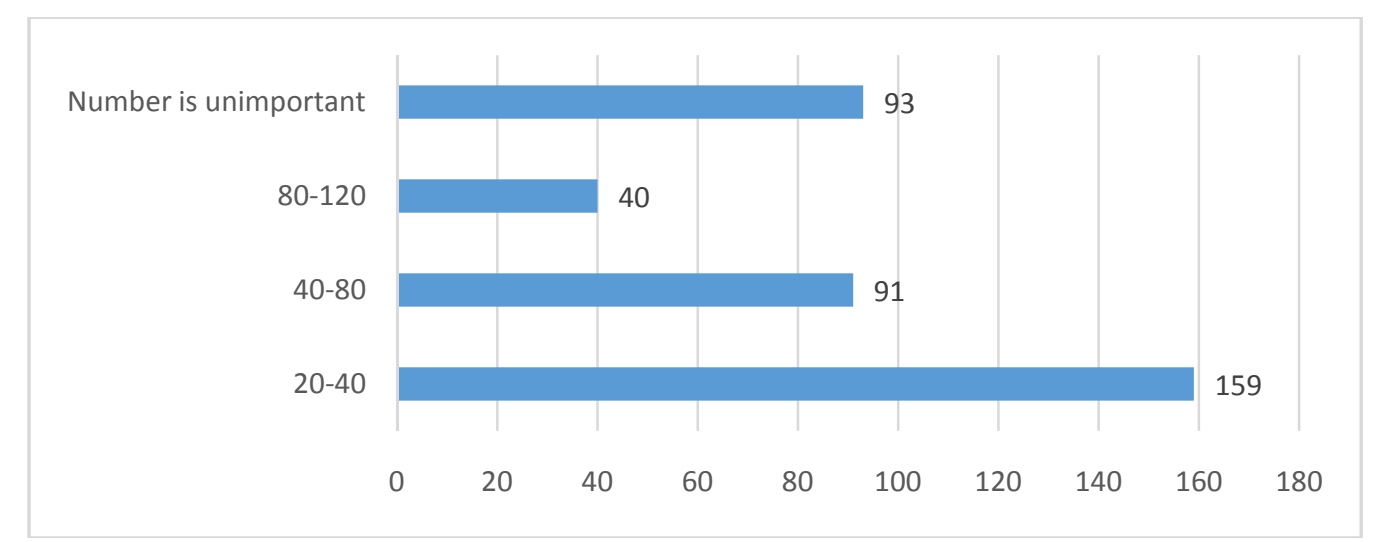

Figure 3. The most suitable number of students in the English language class as perceived by students.

As for students' number in the classroom, 159 (41.5\%) of the students preferred 20-40 students and 131 (34.2\%) favoured that students' number in class should be 40-120 students. In the English class, the students' number was 152 reduced to 130. This finding has an implication for the policy of ELT at U of K in general and the faculty of PEH in particular. Thus, reviewing the current policy toward the teaching of English deemed necessary as suggested by these findings. 
Question 8 in the interview asked about the time allotted to the English language course. The two interviewees indicated that the time was not enough to teach/learn English. The Master's coordinator suggested dividing students into 4-5 groups with smaller numbers to maximize practice time. The AUR coordinator proposed that English should be taught in the five years (10 semesters) to promote students' level of English. These results agree with what was found by Ghenghesh (2013), Altamimi and Shuib (2010), and Eltahir (2010). They concluded that teaching English in one academic year was not enough to improve their students' proficiency in English language. It seems that the time factor is very common, and it is not a problem only found in Sudan. All these studies revealed that the time allotted English language in their context was not enough.

\section{Conclusion}

This study analyzed PEH students' needs for English language. It concludes that PEH students need English for academic study, future jobs, and communication with the outside world. Students are with weak proficiency in English. It was also found that all the macro and micro skills, in the survey, are considered important. Students have various learning needs such as learning in pairs and groups. The study asserts the importance of NA that should be catered for in course design to provide a course that meets students' needs. This may result in a course that motivates students to learn English language. Students of PEH proficiency must be raised to assist them cope with their academic study and future jobs. The $\mathrm{U}$ of $\mathrm{K}$ policy regarding the time for English language should be revised to allow for more hours. It is hoped that this needs analysis will be taken into consideration in designing an ESP course for PEH students.

\section{References}

Abdellah, A., \& Ibrahim, M. (2013). Towards developing a language course fo Hajj Guides in Al-Madinah Al-Munawwrah: A needs assessment. International Education Studies, 6(3), 192-212. Retrieved from www.ccsenet.org/ies

Alastal, A. A., \& Munir, S. (2012). Investigating the academic English language target needs of undergraduates at the Faculty of Applied Science at Al-Aqsa University: Students' perceptions. The Asian ESP Journal, 8(2), 5-26. Retrieved from www.asian-esp-journal.com

Alhuqbani, M. N. (2008). Identifying the English language needs of Saudi police officers. Journal of the Saudi Association of Languages and Translation, 1(2), 55-97. Retrieved from www.salt.net

Ali, A. A. (2011). A needs analysis for designing an ESP syllabus for the students of Sudan Naval Academy (Doctoral dissertation, Al Neelain University).

Alqahtani, M. (2011). An investigation into the language needs of saudi students studying in British postgraduate programmes and the cultural differences impacting on them (Doctoral dissertation, University of Southampton, UK). Retrieved from www.eprints.soton.ac.uk

Altamimi, A., \& Shuib, M. (2010). Investigating the English language needs of Petrolueum Engineering students at Hadhramout University of Sceince and Technology. The Asian ESP Journal, 6(1), 1-30. Retrieved from www.asianesp-journal.com

Basturkmen, H. (2010). Developing courses in English for Specific Purposes. Hampshire: Palgrave Macmillan.

Brindley, G. (1989). The role of needs analysis in adult ESL programme design. In R. K. Johnson (Ed.), The second language curriculum (pp. 63-78). Cambridge: Cambridge University Press.

Brown, J. D. (1995). The elements of language curriculum: A systematic approach to programme development. Boston: Heinle \& Heinle Publishers.

Brown, J. D. (2009). Foreign and second language needs analysis. In M. H. Long and C. J. Doughty (Eds.), The handbook of language teaching (pp. 269-293). London: Wiley-Balckwell.

Chan, V. (2001). Determining students' language needs in a tertiary setting. English Teaching Forum, 39(3), 1-12.

Dafa-Allah, F. E. (2012). ESP learners' needs: A case study of medical students at some Sudanese Universities. English for Specific Purposes World, 12(36), 1-15. Retrieved from www.esp-world.info 
Dornyei, Z. (2003). Questionnaires in second language research: Construction, administration, and processing. London: Lawrence Erlbaum Associates, Publishers.

Dudley-Evans, T., \& St John, M. J. (1998.). English for specific purposes: A multy-disciplinary approach. Cambridge: Cambridge University Press.

Eltahir, H. K. (2010). The relevence of academic business English textbook to students studying needs: A case of second year students (M.A. dissertation, School of Management Science, U of K).

Ghenghesh, P. (2013). Students and teachers of engineering speak out! What do you really need? Arab World English Journal, 4(1), 11-27. Retrieved from www.awej.org

Graves, C. (2000). Designing language courses: A guide for teachers. Boston: Heinle \& Heinle Publishers.

Hutchinson, T., \& Waters, A. (1987). English for specific purposes: A learning-centred approach. Cambridge: Cambridge University Press.

Hyland, K. (2006). English for academic purposes: An advanced resource book. London: Routledge.

Ibrahim, A. M. (2010). ESP at the tertiary level: Current situation, application, and expectation. English language Teaching, 3(1), 200-204. Retrieved from www.ccsenet.org/elt

Long, M. H. (2005). Methodological issues in learner needs analysis. In M. H. Long (Ed.), Second language needs analysis (pp. 19-75). Cambridge: Cambridge University Press.

Lynch, B., \& Tom, H. (1991). EST reading. In M. C. Murcia (Ed.). Teaching English as a second or foreign language (2nd ed., pp. 216-230). Boston: Heinle \& Heinle.

Nugraha, M. (2002). Tringulation of instrumentation and data source: A stronger method in assessing English language needs. K@ta, 4(2), 148-159. Retrieved from http://puslit.petra.ac.id/journals/letters

Nunan, D. (1988). Syllabus design. Oxford: Oxford University Press.

Nur, H. S., \& Mohammed, A. S. E. (2012). The current situation of English at U. of K.: Problems and solutions. Peace University Journal, 2, 201-212.

Richards, J. C. (2001). Curriculum development in language teaching. Cambridge: Cambridge University Press.

Richards, J. C., \& Schmidt, R. S. (2010). Longman dictionary of language teaching and applied linguistics (4th ed.). London: Longman.

Robinson, P. (1991.). ESP today: A practitioner's guide. New York: Printice Hall International.

Rossett, A. (1982). A typology for generating needs assessment. Journal of Instructional Development, 6(1), 28-33.

Seedhouse, P. (1995). Needs analysis and the general English classroom. ELT Journal, 49(1), 59-65.

West, R. (1997). Needs analysis: State of the art. In R. Howard and G. Brown (Eds.), Teacher education for languages for specific purposes (pp. 68-97). London: Multilingual Matters. 